\title{
Diatom ooze and diatomite-diatomaceous sediments in and around the North Pacific Ocean
}

\author{
Itaru Koizumi $^{1 *}$ and Hirofumi Yamamoto ${ }^{2}$
}

The geographical distribution and geological occurrence of diatom ooze and diatomite-diatomaceous sediments were reviewed in and around the middle-high latitude of the North Pacific Ocean including the Bering and Japan seas. Diatoms are the most abundant microfossils found in the bottom sediments of the northern North Pacific Ocean, and the marginal Bering, Okhotsk and Japan seas. The marginal basins in the middle-high latitude of the North Pacific Ocean were formed by tectonic and volcanic activities in the late Oligocene-early Miocene. The early middle Miocene diatomite intercalated with siliceous sandstone to siltstone was deposited in shallow basins. The middle-late Miocene diatomite and diatomaceous mudstone was formed by global cooling and increased primary productivity under anoxic bottom-water conditions at bathyal depths. The late Miocene to early Pliocene diatomite and diatomaceous siltstone formed under oxic bottom-water conditions is widely distributed. During the late Pliocene-Pleistocene, turbidity sands and/or silts capped and diluted the diatomaceous sediment. The timing of these changes in sedimentary facies is simultaneous in the North Pacific region.

Keywords : Neogene North Pacific diatomite, Synchronous geological events, Silica switch, Carbonate Crash

Received 6 October 2017 ; Revised 16 May 2018 ; Accepted 25 May 2018

1 Ocean Research Department, Visiting Researcher in 2000, and IODP Domestic Science Planning Committee, Chairman in 2003-2010 (Emeritus Professor of Hokkaido University)

2 Research and Development Center for Submarine Resources, Japan Agency for Marine-Earth Science and Technology (JAMSTEC)

*Corresponding author:

Itaru Koizumi

Atsubetsu-kita 3-5-18-2, Atsubetsu-ku, Sapporo 004-0073, Japan

itaru@sci.hokudai.ac.jp

Copyright by Japan Agency for Marine-Earth Science and Technology 


\section{Introduction}

Diatom ooze and diatomite-diatomaceous sediments occur concentratedly in and around the middle to high latitudes of the North Pacific Ocean including the Bering, Okhotsk, and Japan seas. Diatom ooze contains large numbers of well-preserved diatom valves, which constitute more than $30 \%$ of the sediment components, and are formed by the sinking of abundant living diatoms in the surface water. The areas of diatom ooze coincide with nutrient-rich regions where high concentrations of nutrient such as nitrogen, phosphorous and silica are typically the result of upwelling ecosystem. With burial and compaction, the diatom ooze is transformed into the siliceous sedimentary rock diatomite, which consists of more than 50-60\% amorphous silica (opal-A, $\mathrm{SiO}_{2} \cdot \mathrm{nH}_{2} \mathrm{O}$ ), the remains of diatom valves with the remainder made up of calcite, organic matter, and terrigenous components. Diatomite is diagenetically transformed into opal-CT (disordered cristobalite-tridymite) at temperatures between $50^{\circ} \mathrm{C}$ and $80^{\circ} \mathrm{C}$ (Hein et al., 1978). The diatomite and diatomaceous deposits form a remarkable belt of Neogene diatomaceous rock along the continental margins of the North Pacific rim, which develops in California, Oregon, Washington, the Aleutian Islands, the Kamchatka Peninsula, Japanese Islands, and the Korean Peninsula (Ingle, 1981).

Diatomite is easily crumbled into a fine white to light yellowish gray powder ranging from 10 to $200 \mu \mathrm{m}$ in particle size. The powder is abrasive and has a low density as a result of its high porosity. The typical chemical composition of diatomite is 80 to $90 \%$ silica, with 2 to $4 \%$ alumina attributed to clay minerals, and 0.5 to $2 \%$ iron oxide. Therefore, diatomite is available commercially in several forms. It is a very famous story that Alfred Nobel (1833-1896) patented the properties of diatomite for the manufacture of dynamite, which could be transported and handled more safely than nitroglycerin and made a fortune during the late nineteen century that now funds the Nobel prizes. After that, the major use of diatomite is in the following main categories: filtration including the purification of beer, liquors, and wine, the cleansing of greases and oils, production of cement, removal of microbial contaminations, mechanical insecticide, absorbent, matting agent, etc (Antonides, 1997; Crangle, 2013). Therefore, the most important field with the Nobel prizes should be "Material Sciences and Earth Sciences" than any other division.

The main purpose of this paper is to review the geographical distribution and geological occurrence based on the geological development of diatom ooze (diatomite) and diatomaceous sediments in and around the North Pacific Ocean including the Bering Sea and Japan Sea.

\section{Diatom ooze and diatomaceous sediments in the North Pacific Ocean}

Diatom ooze are concentrated in the middle to high latitudes of the North Pacific Ocean including the Bering, Okhotsk, and Japan seas (Fig. 1). Diatoms are present in the

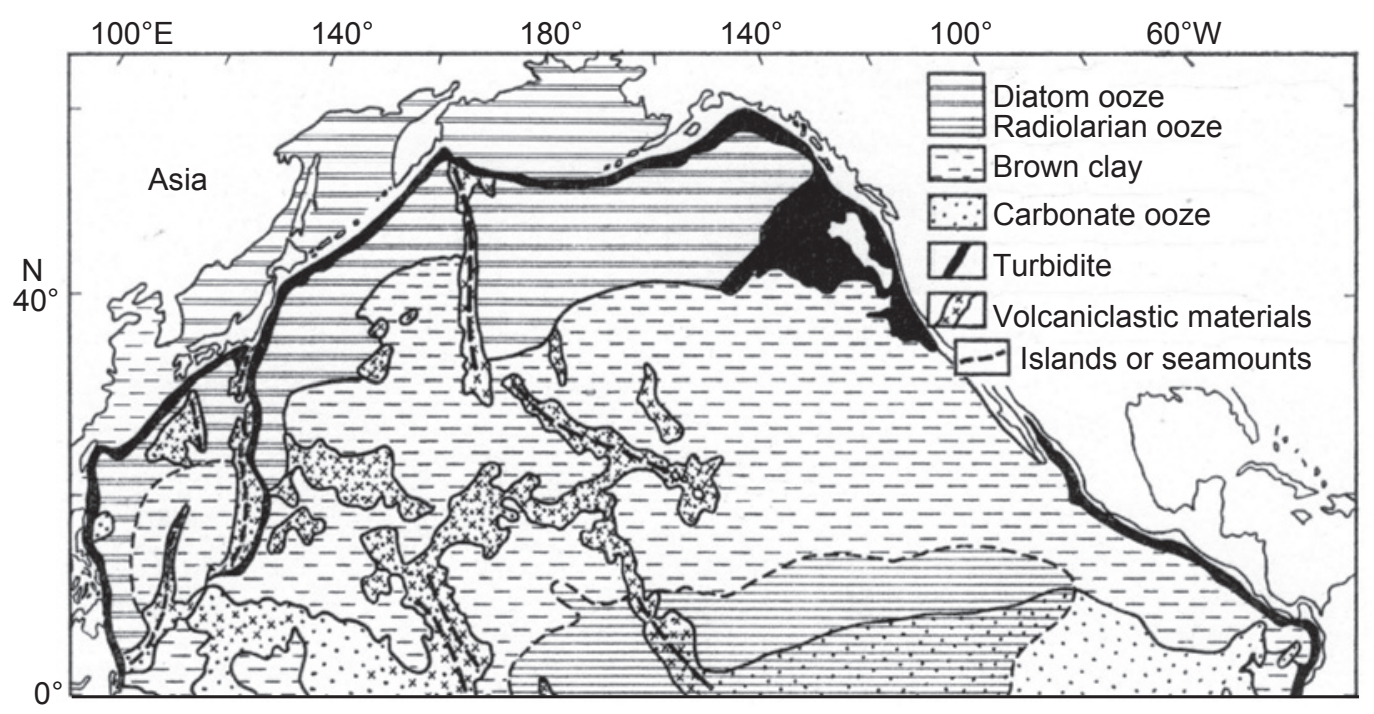

Fig. 1. General patterns of recent sediments in the North Pacific Ocean (Okada and Kobayashi, 1974) 
surface sediments of the seafloor in the North Pacific Ocean and can be used to determine the characteristics of overlying water masses, even though considerable numbers of finely silicified diatom taxa living in surface waters may not be preserved in deep-sea sediments (Kanaya and Koizumi, 1966; Sancetta and Silvestri, 1986; Koizumi, 2008).

The modern North Pacific Ocean is subdivided into three different marine environments by the North Pacific Current which flows across the Pacific at around about $40^{\circ} \mathrm{N}$ latitude: (1) the Alaska Gyre containing cold nutrient-rich water, (2) the Subtropical Gyre containing warm nutrientdepleted waters, and (3) the Mixed Water Region of both subarctic and central water masses between $40^{\circ} \mathrm{N}$ and $42^{\circ} \mathrm{N}$ (Fig. 2).

The Kuroshio Current encounters the Oyashio cold water in the middle latitude of the western area of the North Pacific Ocean and forms a western boundary current. The California Current forms an eastern boundary current joining the flows from the Alaskan Current. The Tsushima Warm Current, a branch of the Kuroshio-bounded western side of the anti-cyclonical Subtropical Gyre, traverses the Japan Sea. Circulation in the subarctic Pacific Ocean is a cyclonic gyre with secondary gyres in the Okhotsk and Bering seas. They are sources for the subarctic water created by vertical and horizontal mixing. Diatom valves are generally well preserved in sediments under the subarctic Alaska Gyre, and the mixed zone of subarctic and central water masses (Fig. 1).

The North Pacific Ocean is the terminus of the deep ocean circulation route originating in the northern North Atlantic and the Southern oceans, and the beginning of the return surface circulation. These old and deep waters are nutrient-rich, oxygen-poor, and highly corrosive to calcium carbonate (Rea et al., 1995b).

\subsection{Northwest Pacific Ocean}

Both Sites 579 and 580 of the Deep Sea Drilling Project (DSDP) are located on the southern margin and in the north portion of the transition zone between the Subtropical and Alaska Subarctic gyres, respectively (Fig. 2). The transition zone defines the convergence of the Kuroshio and Oyashio currents, and is characterized by high biological productivity. The diatom abundances (\%) are based on smear slide analyses by the on board sedimentologists (Shipboard

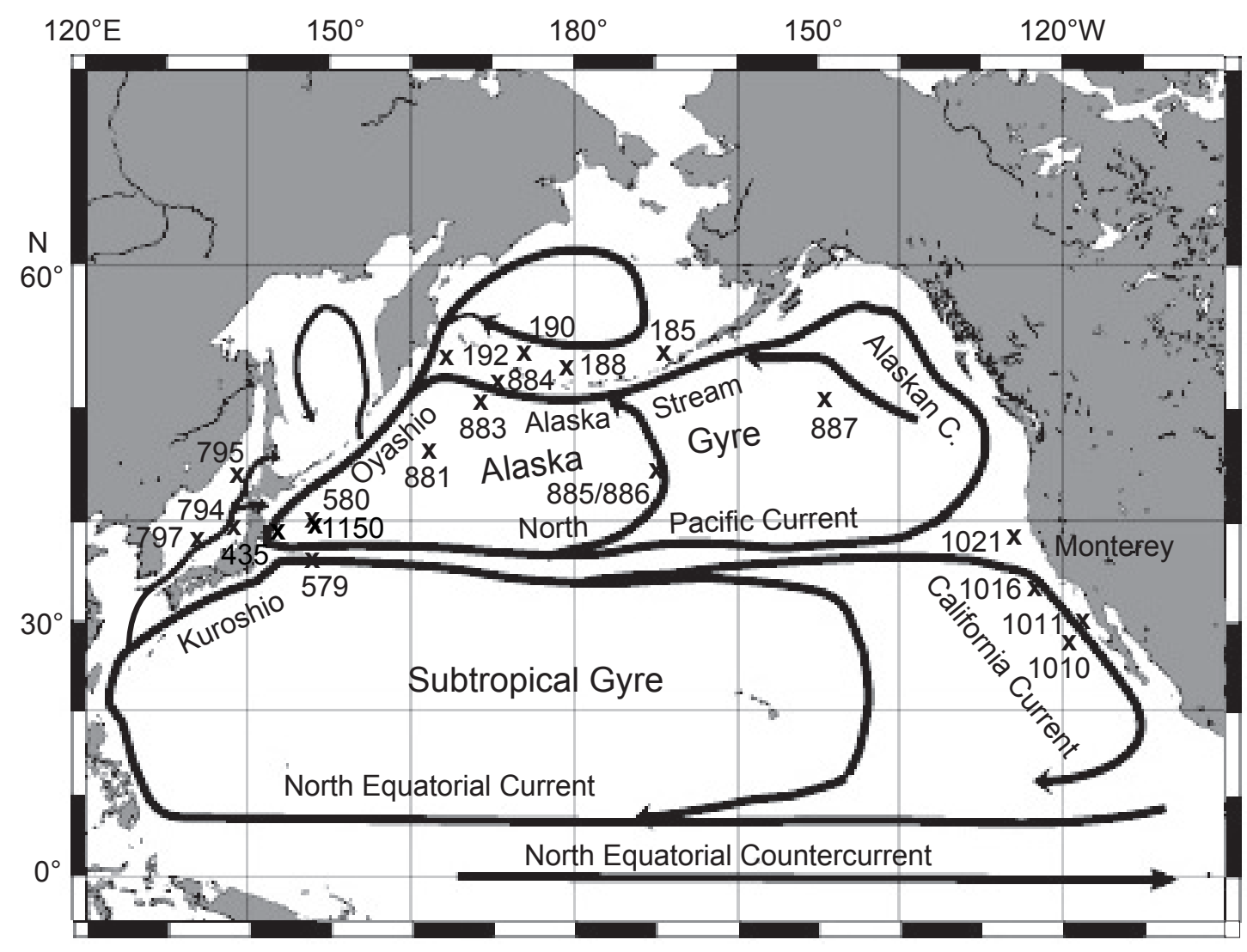

Fig. 2. Surface currents in the modern North Pacific Ocean shown with DSDP and ODP drill sites used in this paper. 
Scientific Party, 1985a, 1985b), and the number of diatom valves per gram of dry sediment $\left(10^{7}\right.$ valves $\left./ g\right)$ are the results of diatom analyses by microscopic examination (Koizumi and Tanimura, 1985).

Site 579 , at a water depth of $5737 \mathrm{~m}$, obtained $149.5 \mathrm{~m}$ of thick lower Pliocene to Pleistocene siliceous clay. The diatom abundances vary according to lithological conditions of sedimentation (Fig. 3). High concentrations of diatoms, about $5.0 \times 10^{7}$ valves/g, are recognized within the lower-upper Pliocene clayey diatom ooze in the interval of 149.5-102.5 mbsf (meters below sea floor). This unit contains 25-60\% diatoms, averaging about 40\% (Shipboard Scientific Party, 1985a). Site 580, at a water depth of $5375 \mathrm{~m}$, obtained $155.3 \mathrm{~m}$ of thick upper Miocene to Pleistocene siliceous clay. The diatom abundances show wide fluctuations throughout the upper Pliocene to lower Pleistocene with an average of about $6.0 \times 10^{7}$ valves/g and in the Pleistocene about $5.0 \times 10^{7}$ valves/g. Diatom abundances increase from 10 to $70 \%$, averaging about $30 \%$. The clayey diatom ooze in the interval of 136.3-117.3 mbsf contains approximately 52\% diatoms (Shipboard Scientific Party, 1985b).

At Site $435,5240 \mathrm{~m}$ deep, located on a slightly flat part of the Japan Trench upper slope, lower Pliocene through lower Pleistocene diatom ooze including 30-50\% diatoms was obtained from in 274.5-244.5 mbsf (Shipboard Scientific Party, 1980). Ocean Drilling Program (ODP) Site $1150,2178 \mathrm{~m}$ deep, is located in the deep-sea terrace on the landward side of the Japan Trench. The upper Pleistocene at 0-1.56, 5.60 and 27.27-31.77 mbsf, and the upper Pliocene at $181.57 \mathrm{mbsf}$ are mainly diatom ooze including 50-60\% diatoms (Shipboard Scientific Party, 2000; Koizumi and Sakamoto, 2003).

At ODP Site 881, $5531 \mathrm{~m}$ deep, located in the deep northwestern Pacific Ocean, a total of $465.2 \mathrm{~m}$ thick of upper Miocene through Pleistocene diatom ooze was obtained (Shipboard Scientific Party, 1993a). Diatom abundances are consistently high within the late Miocene through Pliocene diatom ooze and, on average, greater than $80 \%$ in smear slide analyses (Fig. 3). At the Miocene/Pliocene boundary (5.4 Ma), the mass accumulation rate of diatoms was about $0.4 \mathrm{~g} / \mathrm{cm}^{2} \cdot \mathrm{kyr}$ during the latest Miocene, and increased to more than $1.2 \mathrm{~g} / \mathrm{cm}^{2} \cdot \mathrm{kyr}$ in the early Pliocene (Shipboard Scientific Party, 1993a). Organic carbon increased and remained two to three-fold as much quantity in the ooze throughout the Pliocene and Pleistocene. After the
Pliocene/Pleistocene boundary (2.6 Ma), volcanogenic and terrigenous materials increased. Diatom abundances are high, but variable, in the Pleistocene clayey diatom ooze, with minor amounts of diatom ooze, and generally range between $30 \%$ and $80 \%$ in the smear slide analyses (Fig. 3).

Paleoceanography since the warm Pliocene epoch in the middle latitudes of the northwestern Pacific Ocean was discussed based on diatom assemblages by Koizumi and Yamamoto (2013). The pre-glacial/glacial boundary occurred at $2.85-2.50 \mathrm{Ma}$ in the Mixed Water Region around $40^{\circ} \mathrm{N}$. Around 2.0 Ma, when the latitudinal thermal gradient between the equator and the subtropical/mid-latitudes steepened, and also just after the thermal gradient crossing west-to-east along the equator was formed, the major component of diatom assemblages changed from subtropical-warm neritic diatom Thalassionema nitzschioides s.l. to sub-littoral upwelling diatom Chaetoceros spores, which are a result of primary productivity.

\subsection{Subarctic Pacific Transect}

Subarctic Pacific Ocean includes two major boundary currents, Oyashio and Alaskan currents, and an oceanic and atmospheric frontal zone, Subarctic Front (Fig. 2). Passes through the Aleutian and Kuril arcs provide exchange for deep waters, which exert a strong influence upon the properties of North Pacific Intermediate Water (Rea et al., 1995b). ODP Leg 145, crossed the subarctic Pacific Ocean and established that organic carbon and opal deposition was caused by the activity and productivity of the Oyashio and Alaskan currents in the North Pacific Ocean during the Neogene.

ODP Site 883 was drilled at a water depth of $2385 \mathrm{~m}$ on a level plateau near the summit of Detroit Seamount (Fig. 2). An $830 \mathrm{~m}$-thick layer of sediment was obtained at Site 883 , the interval of $458.0-86.9 \mathrm{mbsf}$ is nearly pure diatom ooze during the time between late Miocene (6.8 Ma) and late Pliocene (2.6 Ma), and represents the rapid siliceous sedimentation with an silica flux of average $3.0 \mathrm{~g} / \mathrm{cm}^{2}$. kyr (Shipboard Scientific Party, 1993b). Dropstones and ash layers are common to abundant in sediment younger than 2.6 Ma after the onset of Northern Hemisphere glaciation. The interval of 597-458 mbsf is middle to upper Miocene calcareous diatom ooze (Fig. 4). Site 884 was drilled at a water depth of $3826 \mathrm{~m}$ on the lower, northeastern flank of Detroit Seamount (Fig. 2), and obtained an 854 m-thick layer 


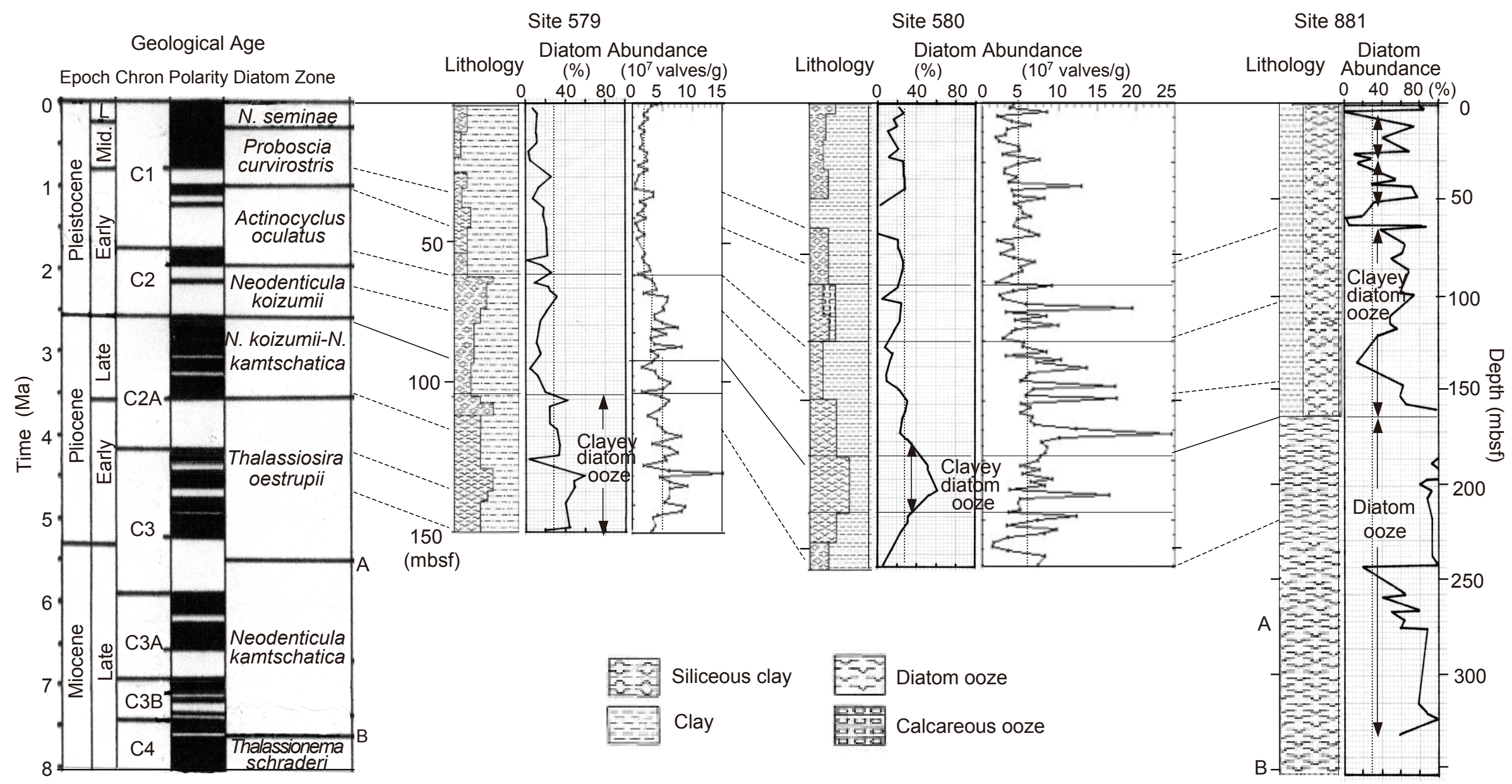

Fig. 3. General lithology, diatom zone, diatom abundance, and diatom ooze of the sedimentary section at DSDP Sites 579 and 580 (Shipboard Scientific Party, 1985a, 1985b), and ODP Site 881 (Shipboard Scientific Party, 1993a) in the northwest Pacific Ocean. A and B at column of Geological Age correspond to A and B of the Site 881 column. 
of Cenozoic sediment (Shipboard Scientific Party, 1993c). Based on the different proportions of clay to diatoms, and the distribution of ash layers and dropstones, the interval of 440.2-128.0 mbsf, age-assigned to the late Miocene to Pliocene, is composed of clayey diatom ooze with less volcanic ashes (Fig. 4). The interval of 604.0-546.1 mbsf, age-assigned to the middle Miocene, is composed of diatomite with clay or sponge spicules and contains no volcanic ashes.

Sites $885 / 886$ were drilled at a water depth of $5713 \mathrm{~m}$ in the eastern margin of the Chinook Trough in the central North Pacific Ocean (Shipboard Scientific Party, 1993d), and obtained a $66 \mathrm{~m}$-thick layer of sediment overlying basalt (Fig. 4). The interval of 50.3-17.3 mbsf is an upper Miocene to lower Pliocene diatom ooze with clay, and diatom abundances range from $54 \%$ to $95 \%$ and, averaging $81 \%$. Sedimentation rates in this interval are in the range of 5 to $6 \mathrm{~m} / \mathrm{myr}$, which increase two to three-hold more than in other sedimentary sections. Especially, diatoms are abundant above $50 \mathrm{mbsf}$ at $9 \mathrm{Ma}$.

Site 887 was drilled at a water depth of $3631 \mathrm{~m}$ in the Gulf of Alaska on the platform level of the PattonMurray Seamounts (Shipboard Scientific Party, 1993e), and obtained a 289 m-thick layer of sedimentary sequence. The interval of $45-0 \mathrm{mbsf}$ is Pleistocene diatomaceous silty clay (Fig. 4). 174-90 mbsf is pure diatom ooze of the latest Miocene-late Pliocene, 235-174 mbsf late Miocene calcareous diatom ooze, and 270-235 mbsf late to middle Miocene siliceous ooze. The mass accumulation rate of diatoms was more than $1.0 \mathrm{~g} / \mathrm{cm}^{2} \cdot \mathrm{kyr}$ through the latest Miocene (5.7 Ma) to Pliocene (2.6 Ma).

All of the sites from Site 881 to Site 887 drilled in Leg 145 showed a rapid accumulation rate of opal (mainly diatoms) during the late Miocene through late Pliocene, and declined at about 2.6 Ma, when major Northern Hemisphere glaciation was established (Fig.4). The Meiji sediment tongue (Scholl et al., 1977) was recognized to be a drift deposit (Rea et al., 1995b). The Meiji Drift contains northern-source diatoms and minerals from the Bering Sea region, and has been accumulating since the early Oligocene. Those sediments were formed by a sediment-laden current moving south through the Kamchatka Strait from the Bering to the northwest Pacific Ocean (Creager, Scholl, et al., 1973; Scholl et al., 1977). The seismic reflection profiles suggest that the Meiji sediment tongue extends $2000 \mathrm{~km}$ along the eastern flank of the Emperor Seamount chain from the
Kamchatka Strait, and was formed by southward-flowing deep-sea currents (Mammerickx, 1985).

\subsection{California Margin}

The California Current system is in the eastern boundary current system of the North Pacific Subtropical Gyre (Fig. 2). The North Pacific Current flows across the Pacific Ocean, separating the cold nutrient-rich waters of the subarctic Alaska Gyre from the warm nutrient-depleted waters of the south. It carries cold and fresh surface water out of the Alaska Gyre, and mixes it with warmer saline water of the Subtropical Gyre. Since the California Current is an eastern boundary current, the region of southward flow diffuses against the cognate western boundary current, the Kuroshio, which flow northward. Coastal upwelling along the California coast is driven by equator-ward winds, and was associated with climate change since the middle Miocene.

During ODP Leg 167, 13 sites were drilled, Sites 1010 through 1022, along the California Margin with coastal and onshore/offshore transects from $30^{\circ} \mathrm{N}$ to $42^{\circ} \mathrm{N}$ (Lyle, Koizumi, Richter, et al., 1997). Site 1021 was drilled at a water depth of $4213 \mathrm{~m}, 100 \mathrm{~km}$ south of the Mendocino Fracture Zone, more than $360 \mathrm{~km}$ from the California Coast, and obtained a $310.2 \mathrm{~m}$-thick sequence of middle Miocene through Pleistocene (12.5-0 Ma) sediments (Fig. 5). The interval of 310.2-204.3 mbsf is characterized by diatom abundant sediment of middle to late Miocene (12.57.0 Ma) indicating high biogenic productivity. From the late Miocene to early Pliocene, the clay component increases considerably.

Near Site 1021, DSDP Leg 18 Site 173 (3957.7’ N, $125^{\circ} 27.1^{\prime}$ W; Water Depth $2927 \mathrm{~m}$ ) locates the continental slope southwest of Cape Mendocino. Diatoms are rich in silty clay from 110 to $120 \mathrm{mbsf}$ (lower Pliocene). The interval from 138 to 285 mbsf (upper Miocene-lower Miocene) is dominated by diatomite, in places with a high nannofossil content. Lower horizons of 285-286 mbsf (lower Miocene) are thin sandy mudstone or chert is underlain by up to 34 meters of glaconitic nannofossil ooze. Andesite (a thick flow or basement) is found at $320 \mathrm{mbsf}$ (The Shipboard Scientific Party, 1973). The diatomite and diatomaceous sediments of the early Miocene through the latest Miocene assigned to the Monterey Shale of California and other similar deposits around the Pacific margin are similar succession: (1) The late Oligocene-early Miocene interval 


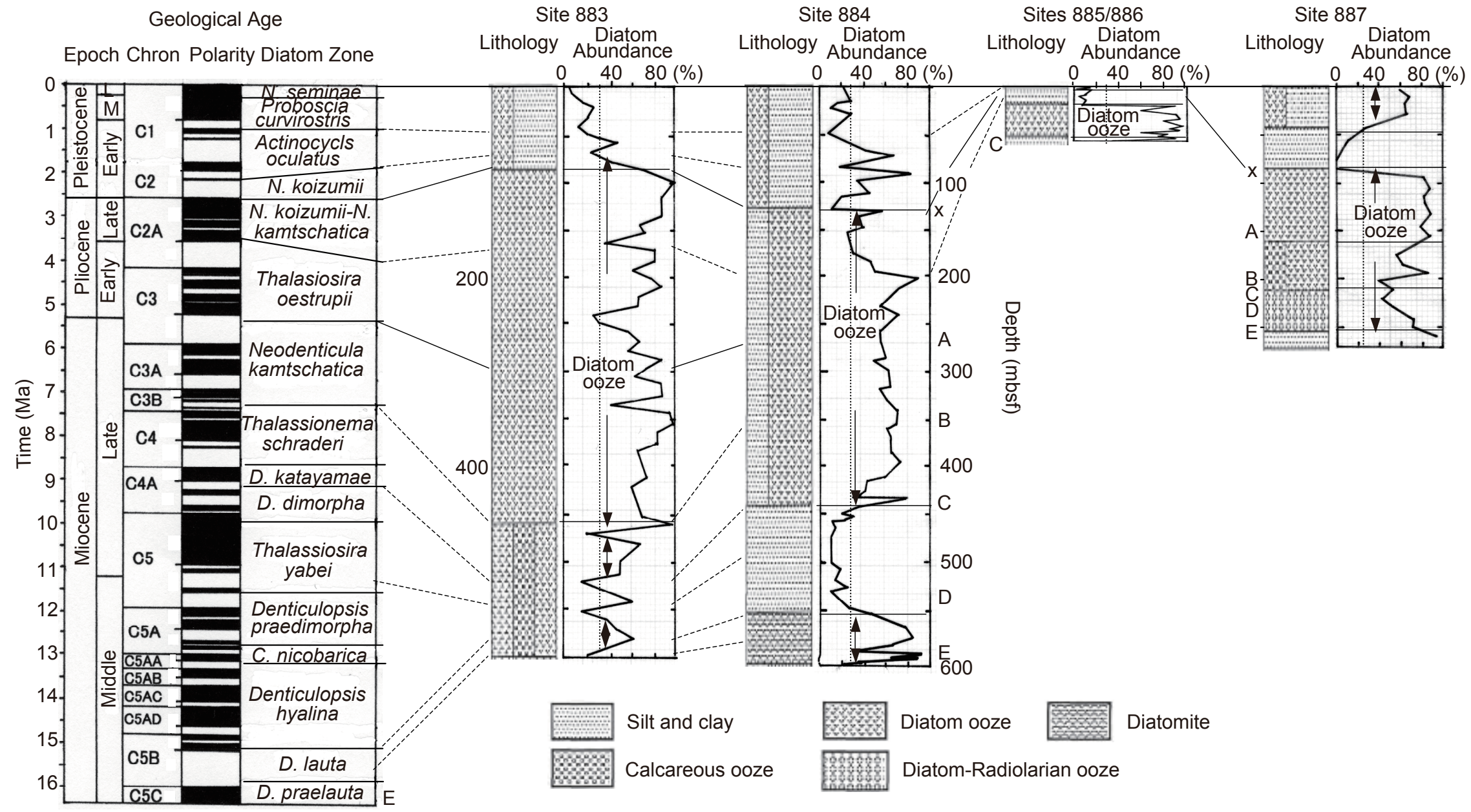

Fig. 4. General lithology, diatom zone, diatom abundance, and diatom ooze of the sedimentary section at ODP Sites 883-887 in the arctic North Pacific Ocean (Shipboard Scientific Party, 1993b, 1993c, 1993d, 1993e). C:Crucidenticula. x, A, B, C, D, and E of the Site 884 column, E at column of Geological Age, and C of the Sites 885/886 column correspond to x, A, B, C, D, and E of Site 887 column, respectively. 


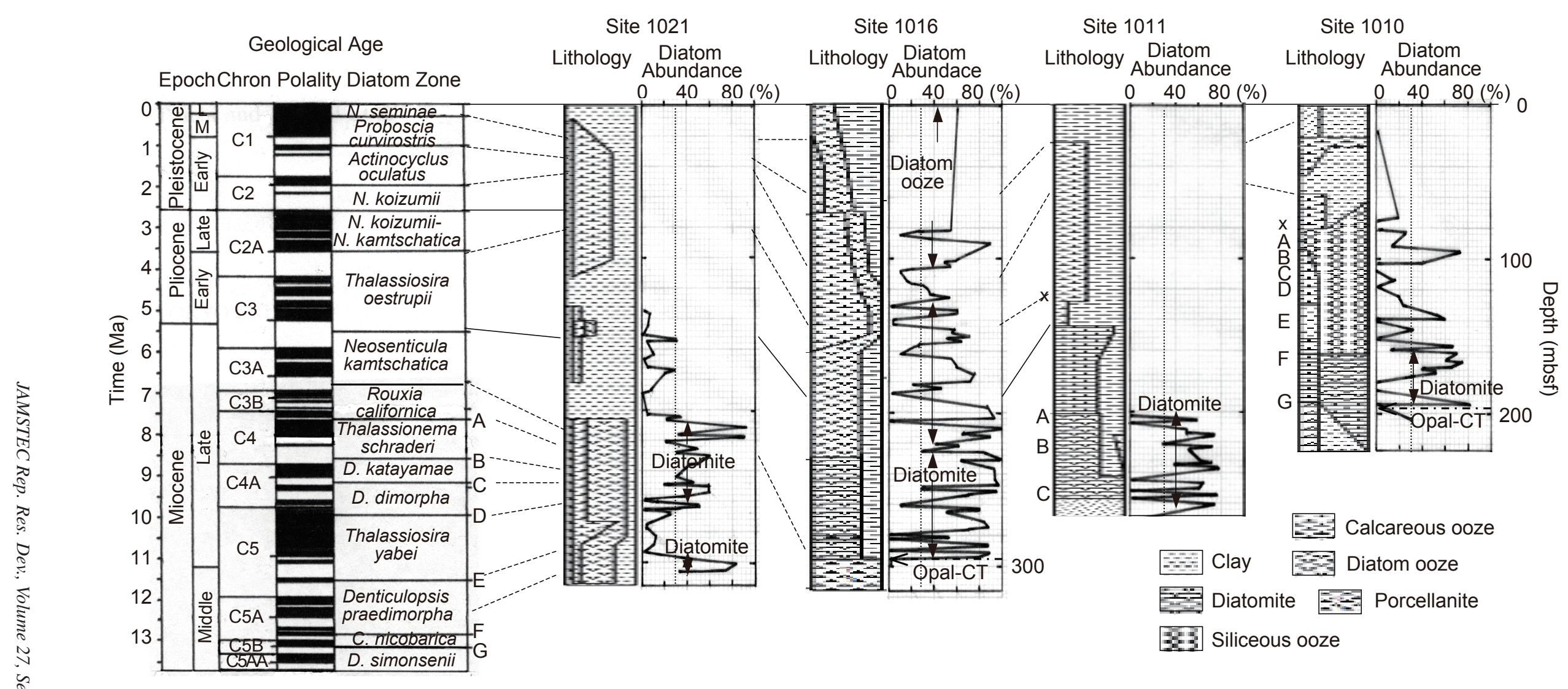

Fig. 5. General lithology, diatom zone, diatom abundance, and diatom ooze of the sedimentary section at ODP Sites 1021, 1016, 1011 and 1010 in the California margin (Shipboard Scientific Party, 1997a, 1997b, 1997c, 1997d; Maruyama, 2000; Lyle et al., 2000). C:Crucidenticula. A, B, C, D, E, F, and G at column of Geological Age, and x, A, B, and C of the Site1011 column correspond to x, A, B, C, D, E, F, and G of Site 1010 column, respectively. 
of volcanics, continental, or shallow marine debris, (2) the middle Miocene diatomite and diatomaceous sediments by rapid subsidence, and (3) The Pliocene and Pleistocene terrigenous clastics capping the diatomaceous intervals (Ingle, 1973).

Site 1016 was drilled at water-depth $3834 \mathrm{~m}, 70 \mathrm{~km}$ from the toe of the continental slope, and about $150 \mathrm{~km}$ west of Point Arguello. The obtained sedimentary section was $316.5 \mathrm{~m}$ thick, and of upper Miocene to Pleistocene (7.5-0 Ma) sequence (Fig. 5). The diagenetic boundary of transition from amorphous silica (opal-A) to cristobalite (opal-CT), corresponding to bottom-simulating reflection (BSR) was found at $298 \mathrm{mbsf}$, and massive chert and porcellanite layers extended down to $316.5 \mathrm{mbsf}$. The interval of 298.0-230.9 mbsf, diatomite and diatom clay under the upwelling conditions, is of upper Miocene (7.56.5 Ma). The interval of 230.9-163.6 mbsf (6.5-4.5 Ma) consists of diatom ooze with clay, and in 163.6-70.0 mbsf (4.5-1.5 Ma) gradually changes into diatom nannofossil ooze to nannofossil diatom ooze. Most of the portion of 70-0 mbsf (1.5-0 Ma) consists of diatom ooze with clay.

Site 1011 was drilled at a water depth of $2022 \mathrm{~m}$ in Animal Basin located about $100 \mathrm{~km}$ of the Ensenada, Mexico in the California Borderland (Fig. 2), and 276.4 m-thick layer of upper Miocene to Pleistocene (9.0-0 Ma) sediments was obtained (Fig. 5). Sediments consist of interbedded siliciclastic clays, nannofossil ooze, and siliceous ooze. At $204.3 \mathrm{mbsf}$ of $7.5 \mathrm{Ma}$, nannofossil chalk with clay changes to diatomite with clay. The underlying unit, 262.1$204.3 \mathrm{mbsf}(8.5-7.5 \mathrm{Ma})$, is characterized by decimeterscale interbedding diatomite, similar to the shoreward basin deposits of the Monterey Formation in California (Shipboard Scientific Party, 1997c). Diatoms compose 50\% to $70 \%$ of the sediment.

Site 1010 is the southernmost deep-water (3480 m) site, which crosses the California Current at about $30^{\circ} \mathrm{N}$. It is located about $100 \mathrm{~km}$ north of Guadalupe Island, seaward of the toe of the Baja California continental slope. A 210.4 m-thick layer of middle Miocene to Pleistocene (15 to $0 \mathrm{Ma}$ ) sedimentary sequence was obtained (Fig. 5). The lower portion of sediments, 148.0-77.5 mbsf (5.5-12.9 Ma, late to middle Miocene), is siliceous ooze containing up to $70 \%-80 \%$ diatoms and radiolarians. The interval of 179.8-148.0 mbsf (13.1-12.9 Ma, middle Miocene), consists of alternating diatomite and nannofossil chalks, and the underlying unit, 210.4-179.8 mbsf, is porcellanite and chert caused by diagenetically formed opal-CT. The Miocene interval characterized by decimeter-scale interbedding of siliceous ooze and diatomite with clay can be correlated to shallower basin deposits in the Monterey Formation.

The deposition of opaline silica derived from diatom valves in the middle through upper Miocene in Sites 1021 and 1010 shows three step-like drops, in comparison to high opal deposition, in the middle Miocene: (1) about 11.5 Ma, (2) about 7.6 Ma which coincides with the end of the Monterey Formation, and (3) 6.5 Ma (Janecek, 2000; Lyle et al., 2000; Barron et al., 2002). Low opal values without high amplitude fluctuations characterize the intervals between 11.5 to $10.0 \mathrm{Ma}, 7.6$ to $6.5 \mathrm{Ma}$, and after $4.6 \mathrm{Ma}$ (Barron et al., 2002). The periods when opal increased prior to 11.5 Ma, 10.0 to 7.6 Ma, and 6.5 to $4.6 \mathrm{Ma}$ coincide with the period when the latitudinal thermal gradient increased and the southward flow of the California Current intensified. The Pliocene ( 4.6 to $2.7 \mathrm{Ma}$ ) is marked by the near absence of diatoms in offshore sites, while diatoms are masked by clastic components in onshore sections.

\subsubsection{Onshore sequences on the California Margin}

The diatom ooze and diatomite was obtained offshore in Leg 167 corresponds to the middle to late Miocene Monterey Formation, which is the most well known marine diatomite and diatomaceous sedimentary sequence in the circum-Pacific (Garrison, 1975; Ingle, 1981; Isaacs, 1983; Barron, 1986; White et al., 1992). The Monterey Formation ranges as old as the late early Miocene, and the thick and pure diatomite is late Miocene to early Pliocene in age. Below the Monterey Formation, three formations develop in the Ventura Basin, California: (1) non-marine Eocene-Oligocene Sespe Formation, (2) upper Oligocenelower Miocene Vaqueros Formation with terrigenous debris, and (3) uppermost Oligocene-lower Miocene Rincon Formation dominated by calcareous nannoplankton (Ingle, 1981). The massive diatomite, siliceous mudstone, and alternation of massive and laminated biosiliceous rocks in the Monterey Formation were deposited in the highstand system tract of the outer shelf (Garrison, 1992). In the Sisquoc Formation of Santa Barbara, opal (diatom) mass accumulation rate (MAR) increases in a series of steps from $10 \mathrm{Ma}$, and reach the highest MAR between 6 and $4 \mathrm{Ma}$. However, diatomaceous siliceous components in the Monterey and Sisquoc Formations were diluted by high influxes of terrigenous debris during the Pliocene (4.6 to 
2.7 Ma).

\subsection{Bering Sea}

The eastern half of the Bering Sea, from Bristol Bay to the Bering Strait, is covered by continental shelf. In contrast, the western half is a deep-sea floor of the Aleutian Basin, which is separated into eastern and western regions by the Shirshov Ridge and the Bowers Ridge (Fig. 6). The Alaskan Stream, an extension of the Alaskan Current, flows westward along the Aleutian Islands and enters the Bering Sea through Near Strait and Kamchatka Strait (Fig. 2). The most significant outflows run through the Kamchatka Strait (Stabeno et al., 1999).

The water above the Bering Sea continental shelf flows out into the Chukchi Sea through the Bering Strait. Inside of the Bering Sea, a large-scale anticlockwise surface water circulation is recognized along the Bering Sea shelf and the Aleutian Islands in the Aleutian Basin. The Bering Sea is a region of high surface productivity owing to the upwelling of nutrient-rich and consequently oxygen-poor deep water.

DSDP Leg 19 in 1971 is still unique in Bering Sea drilling history, but core recovery was poor in quantity and quality (Creager, Scholl, et al., 1973). Afterward, Integrated Ocean Drilling Program (IODP) Expedition 323 (Takahashi and the IODP Expedition 323 Scientists, 2011) provided the continuous Plio-Pleistocene (5-0 Ma) cores.

DSDP Site 192 at a water depth of $3000 \mathrm{~m}$ is located atop Meiji Guyot at the northwest end of the Emperor Seamount chain near ODP Sites 882-884 (Fig. 2). The $1044 \mathrm{~m}$-thick sedimentary section overlies extrusive alkali basalt (The Shipboard Scientific Party, 1973d). The upper Miocene interval of $720-550 \mathrm{mbsf}(9.5-8.0 \mathrm{Ma})$ is diatomaceous clay (The Shipboard Scientific Party, 1973d; Koizumi, 2010). The BSR occurs at about 720 mbsf. The upper Miocene through upper Pliocene interval of 550$140 \mathrm{mbsf}$ (8.0-2.6 Ma) includes diatom ooze, and 1400 mbsf, Pleistocene (0-2.6 Ma), includes abundant ice-rafted pebbles and volcanic ash beds (Fig. 7). Volcanic ash layers also occur in the upper Pliocene interval of 240-140 mbsf (3.1-2.6 Ma).

Site 190 is located at water depth of $3857 \mathrm{~m}$ in the southeastern part of Shirshov Ridge of the southwestern Aleutian Basin (Fig. 6), and a 627 m-thick sediment layer of upper Miocene to Pleistocene sequence was obtained (Fig. 7). The BSR occurs at about 615 mbsf (The Shipboard Scientific Party, 1973c). The upper Miocene mudstone in 627-615 mbsf includes a small piece of middle Miocene diatom-bearing limestone (Koizumi, 1973). The interval of $615-375 \mathrm{mbsf}(6.5-3.6 \mathrm{Ma})$ is worm-burrowed and semi-

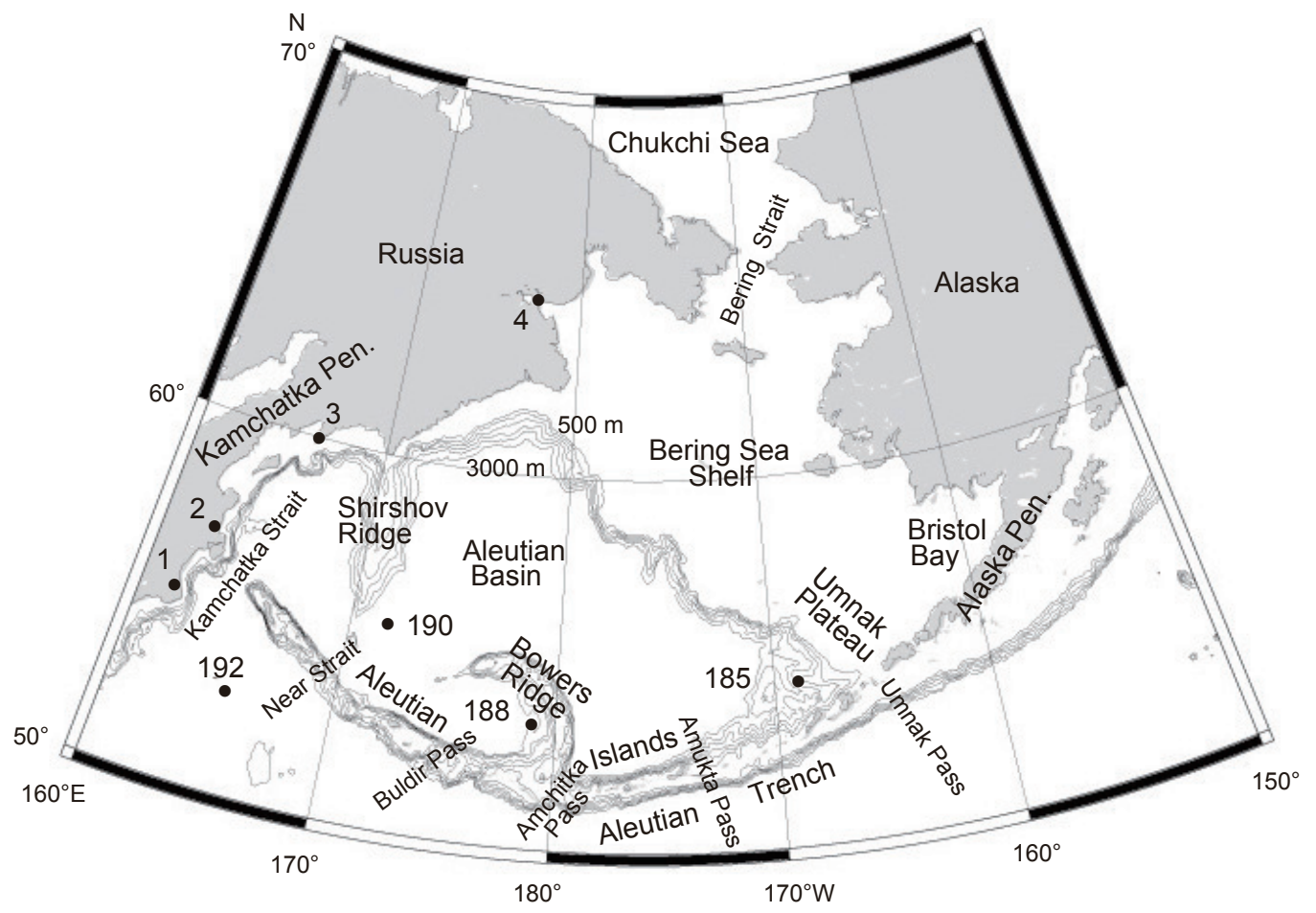

Fig. 6. Topography (Stabeno et al., 1999) and site locations in the Bering Sea. 1:Tjushevskaya, 2:Ust-Kamtschatsk, 3:1l'pinskii, 4:Anadyr 
indurated clayey diatom ooze and diatomaceous silty clay. The interval of $375-175 \mathrm{mbsf}(3.6-1.8 \mathrm{Ma})$ is silty diatom ooze, and $175-0 \mathrm{mbsf}(1.8-0 \mathrm{Ma})$ is diatom-bearing rich silty clay with several size-graded sands and silts (Fig. 7). Displaced freshwater and benthic to littoral diatoms occur in $200 \mathrm{mbsf}$ (2.2 Ma) in diatomaceous silty beds (Koizumi, 1973).

Site 188 is located at a water depth of $2649 \mathrm{~m}$ at the outer edge of the mid-slope terrace on the western flank of Bowers Ridge, and a $638 \mathrm{~m}$-thick sedimentary sequence was obtained. The interval of $580 \mathrm{mbsf}$ to $315 \mathrm{mbsf}$ (5.5$2.2 \mathrm{Ma}$ ), semi-consolidated diatom ooze and diatomaceous silts, overlies the mudstone (638-580 mbsf) lacks diagnostic fossils (The Shipboard Scientific Party, 1973b). The BSR occurs at $580 \mathrm{mbsf}$. The interval of 315-0 mbsf (2.2-0 Ma) is unconsolidated diatom ooze accompanying volcanic ash layers, sands and silts. Very hard and fractured black mudstone occurs at $273 \mathrm{mbsf}$ ( 2 Ma).

Site 185 at a water depth of $2110 \mathrm{~m}$ is located on the southern flank of the broad spur, southeastern Bering Sea. A $728 \mathrm{~m}$-thick sedimentary sequence was obtained (The Shipboard Scientific Party, 1973a). The upper Miocene through Pleistocene interval of $600-0 \mathrm{mbsf}(6-0 \mathrm{Ma})$ is clayey diatom ooze, and diatom content ranges from $40 \%$ to a maximum of $90 \%$, about $65 \%$ on average. Ice-rafted exotic pebbles, volcanic ash layers, and very hard and fractured black mudstone occur at 120-100 mbsf (2.6-2.0 Ma) at the Plio-Pleistocene boundary (Fig. 7). The BSR occurs at 587670 mbsf.

The Miocene through Pleistocene diatom biostratigraphy, recognized in the drill cores which were obtained in Leg 19, was revised (Koizumi, 2010). The basal part of the lithologic unit A (opal-A), diatom ooze and diatomaceous mud, which overlies the unit B (opal-CT), mudstone with no diatoms, distinctively forms a diachronic plane.

\subsubsection{Onshore sequences in the Kamchatka Peninsula and Chukchi}

The diatomite in the Cape Plosky, Yunjuvayamian, Limimtevayamian, and Ust-Limimtevayamian Suites in Tjushevskaya and Ust-Kamchatska of eastern Kamchatka is age-assigned to the late Miocene (9.5 Ma) through late Pliocene (3.5 Ma) based on diatoms (Gladenkov, 1984). The diatomite sequence from 796.8 to $580.5 \mathrm{mbsf}$ was obtained from Hole Central-1 at a water depth of $90.1 \mathrm{~m}$ on the
Chukchi shelf of the Anadyr Depression and recognized to be of middle Miocene through lower Pliocene age based on the lithology and diatom assemblage (Gladenkov, 2013a). The oldest marine diatoms in the lower course of the Anadyr River were previously reported as late Eocene to Oligocene age (Sheshukova-Poretzkaya, 1968), and, further, a middle Eocene diatom assemblage was reported from the Kylan Formation of the Il'pinskii Peninsula, northeastern Kamchatka (Gladenkov, 2013b).

\subsection{The Japan Sea}

The Japan Sea is a semi-enclosed marginal sea located at the eastern end of the Asian continent with its eastern margin bounded by the Japanese Island Arc (Fig. 8). The Japan Sea is divided into two different parts by the Yamato Rise at $40^{\circ} \mathrm{N}$ parallel. The Yamato Rise, which represents a slab of rifted continental crust, is composed of two major banks, Kita-Yamato Bank and Yamato Bank separated by a longitudinal depression, the Kita-Yamato Trough. The northern half of the sea is comparatively simple, but the Japan Basin and the southern half possess complex bathymetry characterized by a series of basins and ridges.

Water exchange between the Japan Sea and adjacent seas has mainly occurred through four narrow and shallow straits (Fig. 8). Therefore, it has responded to eustatic sea-level changes influenced by tectonic and climatic changes. The main current, Tsushima Warm Current, which is a branch of the Kuroshio, meanders in the southern part and then flows out into the North Pacific Ocean through the Tsugaru Strait and Okhotsk Sea through the Soya Strait.

Upper Miocene through upper Pliocene diatom ooze has been recognized earlier using the Lamont-Doherty Geological Observatory (L-DGO) piston cores which were obtained around the periphery of the Yamato Rise, and RC12-377 obtained at the western end of the Marginal Plateau off the Oki Island (Koizumi, 1978; Koizumi and Yamamoto, 2017). On the other hand, the diatomaceous clay at 601-260 cm depth in RC12-394, taken from the northeast flank of the Yamato Rise (Fig. 8), is age-assigned to lower Miocene, and of brackish-water origin accompanying the Daijima-type flora (Koizumi, 1988).

ODP Site 797 is located at a water depth of $2862 \mathrm{~m}$ in the southwestern Yamato Basin, and a $900 \mathrm{~m}$ thick sequence of lower Miocene carbonaceous siltstone and obtained sandstone intercalated with altered basalts 


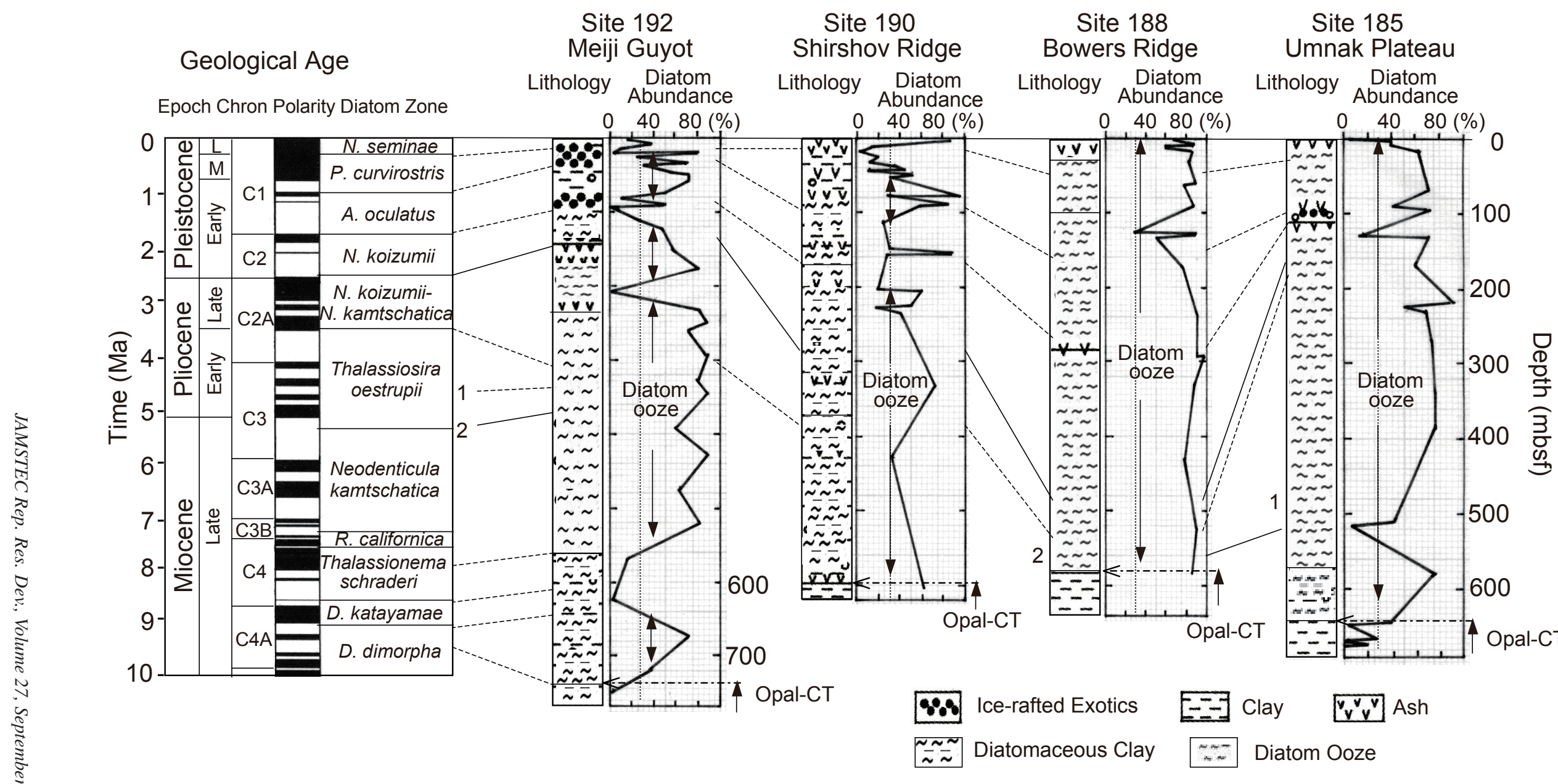

Fig. 7. General lithology, diatom zone, diatom abundance, and diatom ooze of the sedimentary section at DSDP sites in the arctic North Pacific Ocean and Bering Sea (Creager, Scholl, et al., 1973; Koizumi, 1973, 2010). P.:Proboscia, A.:Actinocylus, R.:Rouxia, D.:Denticulopsis. 1:last occurrence of Thalassiosira insigna, 2:first occurrence of Thalassiosira oestrupii. 
was recovered (Shipboard Scientific Party, 1990c). The upper Miocene through upper Pliocene interval of 224.0$119.9 \mathrm{mbsf}$ is a clayey diatom ooze with diatom abundance of $4.08 \times 10^{7}$ valves/g on average, and in the upper Pliocene interval of 119.0-90.0 mbsf, diatoms increase in abundance of $7.07 \times 10^{7}$ valves/g on average (Fig. 9). The diagenetic opal-A/opal-CT (cristobalite) boundary occurs between 294.3 and 299.1 mbsf.

Site 794 is located at a water depth of $2811 \mathrm{~m}$ in the northern Yamato Basin, and a $544 \mathrm{~m}$-thick sequence of middle Miocene claystone was obtained at $654 \mathrm{mbsf}$ (Shipbord Scientific Party, 1990a). The upper Miocene through upper Pliocene interval of 216.9-92.3 mbsf is diatom ooze in which the diatom abundance is $2.8 \times 10^{7}$ valves $/ \mathrm{g}$ on average, peaking to $7.7 \times 10^{7}$ valves/g twice. Further in the lower-middle Pleistocene diatom abundance increases remarkably, also peaking to $15.4 \times 10^{7}$ valves/g twice. The diagenetic opal-A/ opal-CT boundary occurs at about
300 mbsf.

Site 795 is located at a water depth of $3300 \mathrm{~m}$ in the northern Japan Basin (Shipbord Scientific Party, 1990b). Pleistocene to middle Miocene clay, diatom ooze, diatom claystone, siliceous claystone, tuff, and claystone with minor pyroclastics during the interval of 0-684 mbsf, and basalitic andesite and basalts in 684-761 mbsf were obtained. The lower to upper Pliocene interval of 325$123 \mathrm{mbsf}$ is diatom ooze including more than $30 \%$ diatoms by smear slide analysis, and diatom abundances are, on average, $6.6 \times 10^{7}$ valves/g (Fig. 9). The Pleistocene silty clay indicates increasing diatom abundance with peaks at $60 \mathrm{mbsf} 15.5 \times 10^{7}$ valves/g and at $10 \mathrm{mbsf} 7.7 \times 10^{7}$ valves/g. The diagenetic opal-A/ opal-CT boundary occurs at about 325 mbsf.

Upper Miocene through Pliocene diatomite and diatomaceous sediments are distributed widely on the floor of the Yamato and Japan Basins, and form the

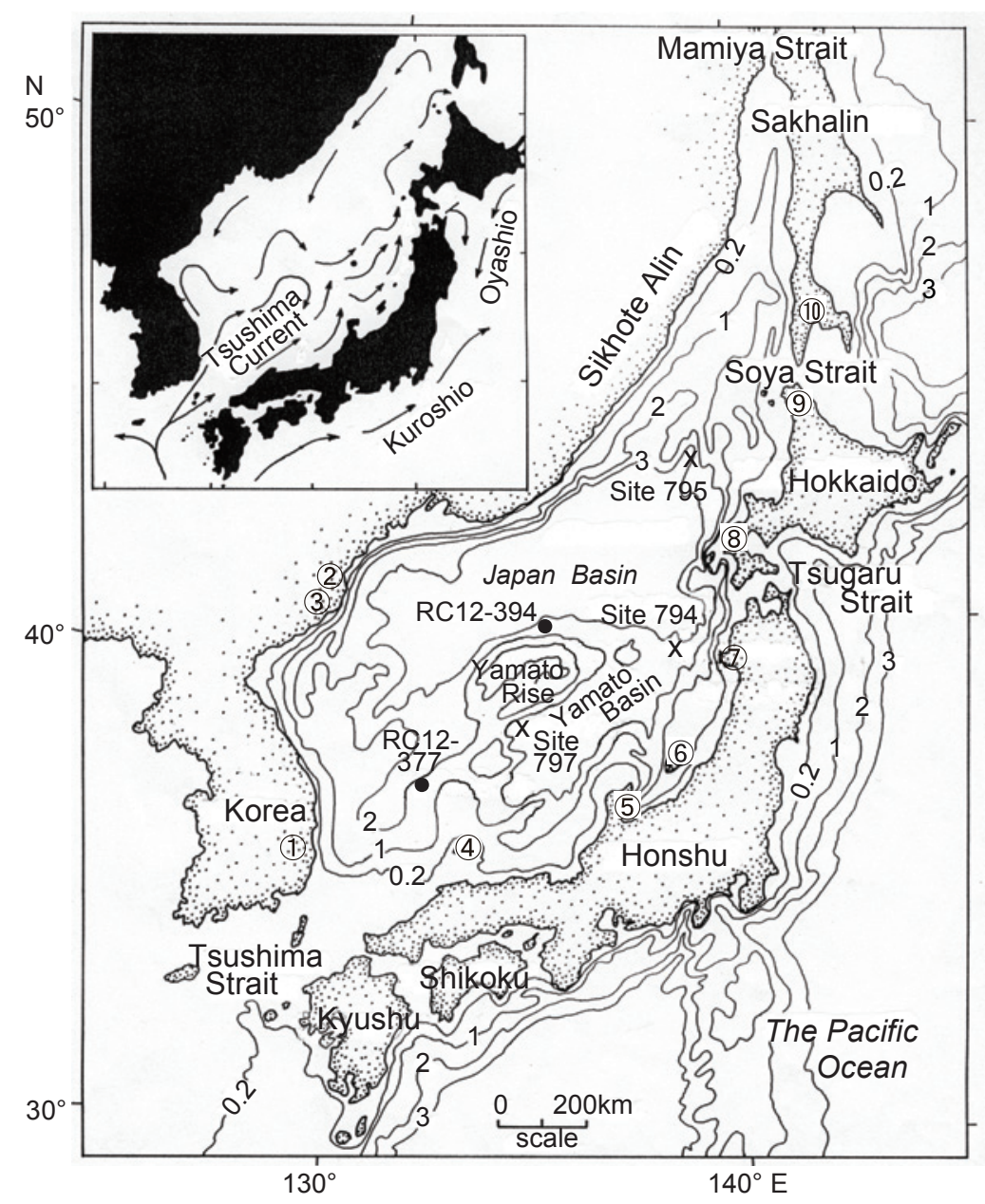

Fig. 8. General bathymetry (km) and site locations in the Japan Sea. (1) : Changgi, (2) : Yongdong, (3) : Hamjindong, (4) : Oki Islands, (5) : Noto Peninsula, (6) : Sado Island, (7) : Oga Peninsula, (8) : Southern Hokkaido, (9) : Northern Hokkaido, (10) : Southern Sakhalin. 


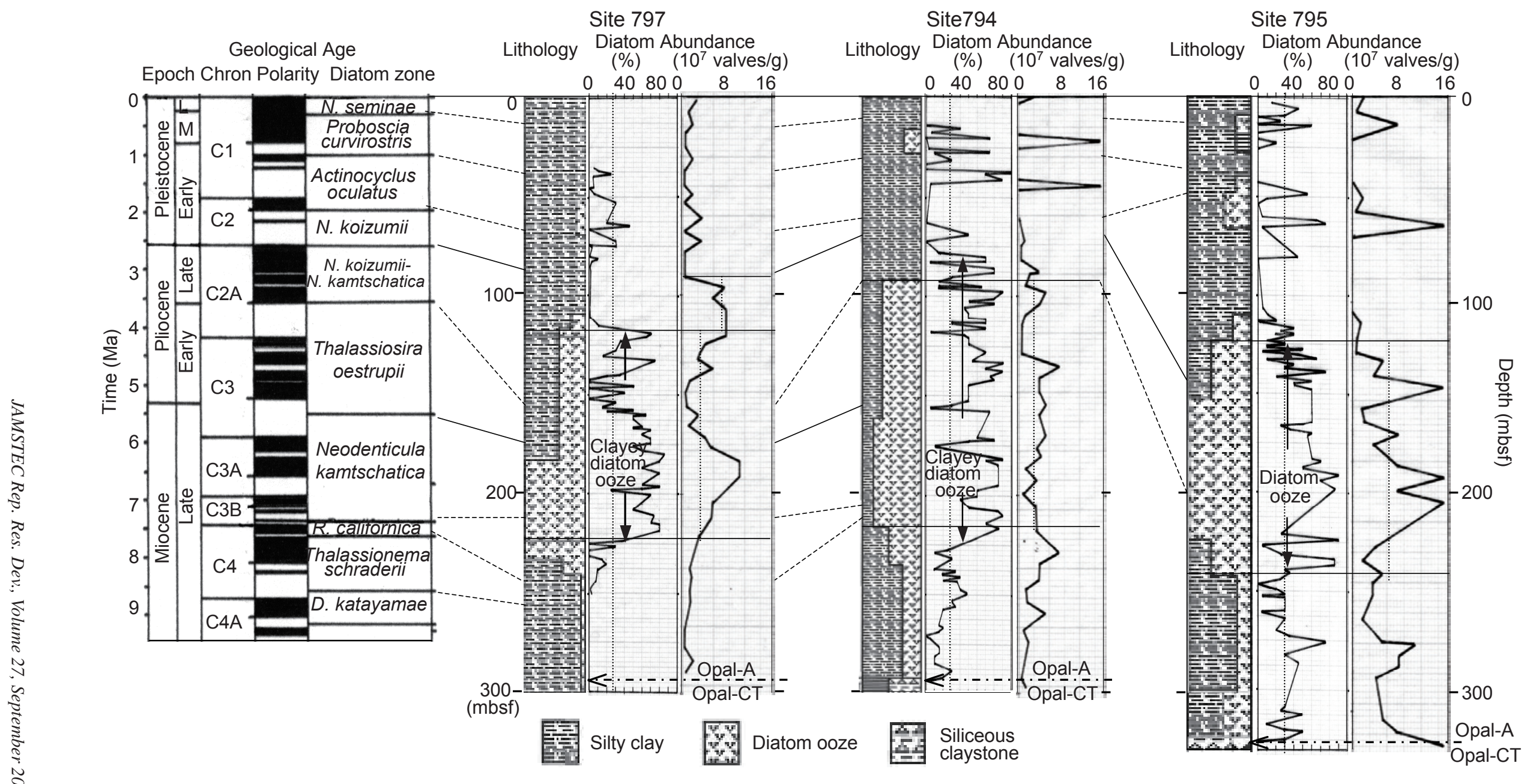

Fig. 9. General lithology, diatom zone, and diatom abundance of the sedimentary section at ODP sites in the Japan Sea (Shipboard Scientific Party, 1990a, 1990b, 1990c; Koizumi, 1992). R:Rouxia, D:Denticulopsis 
topographical mound such as Oki and Yamato ridges. In diatom assemblages contained in the diatomite and diatomaceous sediments, which L-DGO cores and Sites 794797 obtained, cold-water species dominates, but warm-water species appear 3.5 Ma at Site 794 and 3.0 Ma at Site 797. It indicates that the Japan Sea opened in the northern area but was almost closed in the south near the Tsushima Strait from the late Miocene to the Pliocene age. A warm-water (paleo-) Tsushima Current did not penetrate into the Japan Sea through the (paleo-) Tsushima Strait during the late Miocene through Pliocene age (Koizumi, 1992).

\subsubsection{Onshore sequences around Japan Sea}

The Japan Sea opened by the rifting along the eastern margin during the late Eocene to Oligocene based on the litho- and chrono-stratigraphy in the back-arc onland subaerial to shallow-water successions (Kano et al., 2007), and ended during the late Pliocene to Pleistocene (Ingle, 1975; Koizumi, 1983). Initial slow rifting was rapidly accelerated, and rifting and spreading established through temporal thermal doming during the early to middle Miocene at 20-15 Ma (Kano et al., 2007). The late Oligocene to early Miocene diatomite and diatomaceous sediments consists of terrestrial to lacustrine deposits and shallow marine volcanic rocks, and contains the cool Aniai-type flora different from a warm Daijima-type flora (Koizumi, 1988).

The diatomite and diatomaceous sediments accompanied with the Aniai-type floras are fresh-brackish water in origin. And the Chojaburu Diatomite of Iki Islands, the Yamatoda Diatomite of Noto Peninsula, and the Magaribuchi Formation of northern Hokkaido are listed as the same type of sediments (Fukusawa and Koizumi, 1994). In the Pohang section of South Korea, the lower Miocene diatomaceous mudstone and diatomite was obtained and includes $40-70 \%$ siliceous microfossils, predominantly diatom (Garrison et al., 1979; Ingle, 1992). Also the Aniaitype floras are preserved in the laminated mudstone or shale in the lower part of the Pohang section (Koizumi, 1988).

The lower to middle Miocene marine sediments that accumulated during the time of rapid spreading and subsidence around Japan Sea contributed to a nearly continuous sequence, which is exposed on the Oga Peninsula of northeastern Japan and can be correlated with most of the onshore Neogene sequences which are widely scattered along the eastern margin of the Japan Sea (Koizumi et al., 2009). The diatomite and diatomaceous sediments are subdivided mainly into three stages (Koizumi, 1983; Koizumi and Yamamoto, 2017): (1) The early middle Miocene diatomite in Kumi of Oki Islands, Hojuji, Iida and Nadaura of Noto Peninsula, and Hirasawa of Oga Peninsula, and intercalated with siliceous sandstone and siltstone, which contain glauconite and phosphate. (2) The middle to late Miocene diatomite and diatomaceous mudstone was deposited in Iizuka, Wakura and Sugata in Noto Peninsula, Nakayama of Sado Island, Onnagawa of Oga Peninsula, Tsuzureko and Yorinobe of Akita Prefecture, Numanokubo of Iwate Prefecture, and Maruyamskaya of southern Sakhalin. This deposition was related to global cooling, and increased primary productivity under dysoxic to anoxic bottom-water conditions at bathyal depths (Ingle, 1981; Koizumi, 1983). (3) The late Miocene to early Pliocene diatomite and diatomaceous siltstone that accumulated under oxic bottom-water conditions that are widely distributed in Yabuta of Noto Peninsula and Enbetsu of Hokkaido. By the Pleistocene, turbidite sands and/or silts capped and diluted the diatomaceous sediments. During the early Pleistocene, bathyal turbidite sequences and neritic deposits rapidly filled basins, and an episode of uplift and folding in the Neogene basinal sequences followed during the late Pleistocene.

\section{Conclusions}

The Neogene diatomite and diatomitediatomaceous sediments in and around the margin of the North Pacific Ocean occur within similar tectonic, stratigraphic, and paleoenvironment histories in spite of widely separated areas (Fig. 10). They were formed by synchronous geological events: (1) volcanic, continental to shallow marine clastics and coal layers deposited in the marginal basin by tectonics and volcanism during the late Oligocene to early Miocene age, (2) silled marginal basins subsided and then developed, and was followed by deposition of marine coarse calcareous sandstone which contain shallow warm marine mollusks and larger foraminifera in the early Miocene age (Ingle, 1973), (3) the area of silica deposition shifted from the North Atlantic Ocean to the North Pacific and Indian oceans, the so-called "silica switch", in the early middle Miocene (Keller and Barron, 1983; Koizumi, 1990; Rea et al., 1995b), (4) diatom ooze and diatomaceous sediments were deposited in the silled margin basins under anaerobic waters with phosphates 


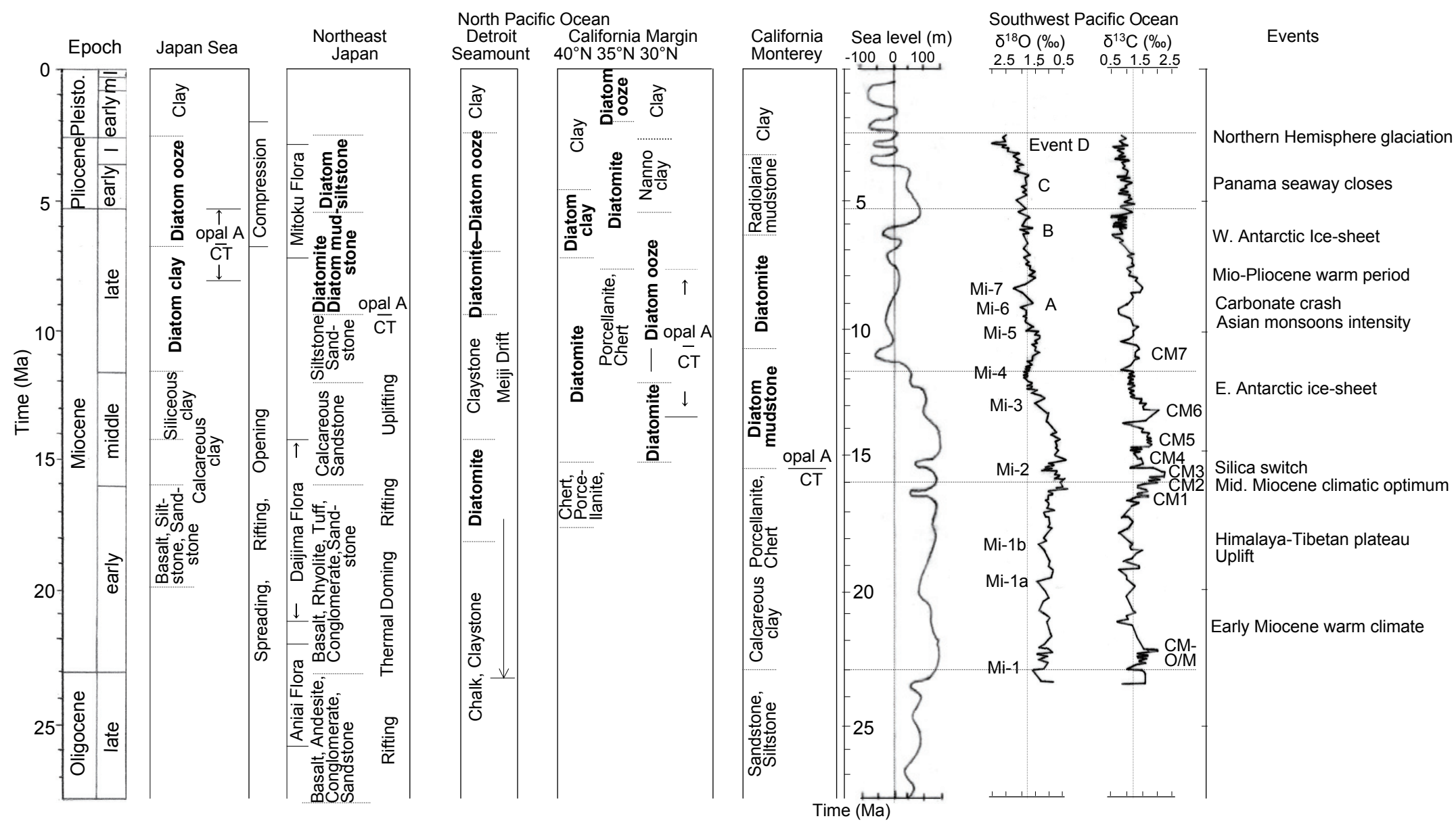

Fig. 10. Correlation of the Neogene marine sequences, including diatomaceous sediments and genetically related porcellanites and cherts, in and around the margin of the North Pacific Ocean, eustatic sea level curve (Haq et al., 1987), benthic $\delta^{18} \mathrm{O}$ and $\delta^{13} \mathrm{C}$ data in DSDP Sites 588 and 590 of the southwest Pacific (Kennett, 1986), and tectonic and climatic events (Pagani et al., 1999; Zachos et al., 2001). Mi: Miocene isotope events represent inferred glacial maxima (Miller et al., 1991; Pagani et al., 1999). CM: Carbon maxima events represent inferred episodic organic carbon burial (Woodruff and Savin, 1991; Pagani et al., 1999). Event A-D: Changes in diatom MAR with spliced benthic $\delta^{18} \mathrm{O}$ in Sites 588 and 590, and with major events by closure of the Panama Isthmus (Barron, 1998). 
during the middle to late Miocene and Pliocene age, (5) amorphous silica (opal-A) was diagenetically transformed to cristobalite-tridymite (opal-CT) (Creager, Scholl et al., 1973; Hein et al., 1978), and (6) coarse terrigenous clastics were rapidly deposited and capped underlying diatomaceous sediments during the late Pliocene-Pleistocene age (Ingle, 1973, 1981; Keller and Barron, 1983; Koizumi, 1990; Tamaki et al., 1992; Rea et al., 1995a; Barron, 1998; Koizumi et al., 2009).

The general regressions and transgressions recognized in the sea level curve coincide with the epoch boundaries, and increases and decreases in benthic (Cibicidoides spp.) $\delta^{18} \mathrm{O}$ and $\delta^{13} \mathrm{C}$ values (Fig. 10). Fluctuations in benthic $\delta^{18} \mathrm{O}$ values explain nine glacial intervals (from Mi-1 to Mi-7, and Mi-1a and Mi-1b), and $\delta^{13} \mathrm{C}$ values and seven peaks of increasing organic carbon burial (from CM1 to CM7), respectively, during the Miocene (Woodruff et al., 1981; Miller et al., 1991; Woodruff and Savin, 1991; Pagani et al., 1999). The benthic $\delta^{18} \mathrm{O}$ is low during the early Miocene, indicating the middle Miocene climatic optimum at 16.5-15.5 Ma. Major increases, however, occur at $15.5 \mathrm{Ma}$ (Mi-2), and between 15.0 and $12.0 \mathrm{Ma}$ with $\mathrm{Mi}-3$ at $13.0 \mathrm{Ma}$ and $\mathrm{Mi}-4$ at 12.0 Ma. The high $\delta^{13} \mathrm{C}$ values fluctuate between 17 and $13 \mathrm{Ma}$ and coincide with increases in $\delta^{18} \mathrm{O}$ values. Sea level drops, especially at $11 \mathrm{Ma}$ just after Mi-4, and keeps today's level with small rises and drops during the late Miocene. Those events indicate the major permanent accumulation of the East Antarctic ice sheet and cooling of bottom waters. High-latitude surface waters cooled while low-latitude water temperatures warmed (Flower and Kennett, 1993), leading to a stronger latitudinal temperature gradient, increased vertical-water mass stratification, and inferred strengthened surface water circulation (Pagani et al., 1999). However, the increase of benthic $\delta^{13} \mathrm{C}$ values (CM7) in the early late Miocene at $11.5-10.5 \mathrm{Ma}$ is not supported by sea level regression and a further increase in benthic $\delta^{18} \mathrm{O}$ values after Mi-4.

Global Miocene climatic events shifted from a nonglacial to glacial climate, and this shift was responsible for acceleration of upwelling and diatom productivity, beginning at 16-15 Ma, in the marginal North Pacific Ocean. Climatic cooling also occurs at 10.0 Ma (Mi-5), 9.0 Ma (Mi6) and $8.5 \mathrm{Ma}(\mathrm{Mi}-7)$ in the early late Miocene. During the middle Pliocene, increase in benthic $\delta^{18} \mathrm{O}$ suggests increasing global ice volume and cooling of bottom waters.
After that, during 2.6 and $2.4 \mathrm{Ma}$, the onset of Northern Hemisphere glaciation occurred.

Four major changes in diatom mass accumulation rates (MARs) occurred in response to high-latitudes cooling and changes in surface and deep waters circulation due to shoaling of the Panama Isthmus (Barron, 1998). (1) At 9 Ma (Event A), diatom MARs increased in the northwest Pacific Ocean by an enrichment of nutrients in North Pacific deep waters and "carbonate crash" (Lyle et al., 1995) due to shoaling of the Panama Isthmus. (2) Before 6.2 Ma (Event B), a major cooling event occurred in the high latitudes of the southern Pacific Ocean by the expansion of the western Antarctic ice-sheet at about 6.5 Ma (Kennett, 1986) and the onset of "latest Miocene-earliest Pliocene biogenic bloom" began in the eastern equatorial Pacific Ocean at $6.7 \mathrm{Ma}$ (Farrell et al., 1995). (3) At about 4.5 Ma (Event C), diatom productivity decreased in sub-boreal to boreal areas but increased in the northwest Pacific Ocean due to warmer temperature during the Mio-Pliocene warm period (Barron, 1998) and paleoceanographic changes due to shoaling of the Panama Isthmus (Haug et al., 1995). (4) After 2.7 Ma, diatom MARs declined abruptly and coincidently with a major increase in ice rafted detritus in the high latitudes of the North Pacific Ocean caused by the rapid onset of major Northern Hemisphere glaciation (Haug et al., 1995; Barron, 1998; Prueher and Rea, 1998).

\section{Acknowledgements}

We gratefully acknowledge Dr. John A. Barron of an Emeritus Research Geologist, U.S. Geological Survey and two anonymous reviewers for critical reviews and suggestions for improving the manuscript.

\section{References}

Antonides, L.E. (1997), Diatomite. U.S. Geological Survey, Mineral Commodity Summaries, 24.1-24.4.

Barron, A.A. (1986), Paleoceanographic and tectonic controls on deposition of the Monterey Formation and related siliceous rocks in California. Palaeography, Palaeoclimatology, Palaeoecology, 27, 27-45.

Barron, J.A. (1998), Late Neogene changes in diatom sedimentation in the North Pacific. Journal of Asian 
Earth Sciences, 16, 85-95.

Barron, J.A., M. Lyle, and I. Koizumi (2002), Late Miocene and early Pliocene biosiliceous sedimentation along the California margin. Revista Mexicana de Cincias Geológicas, 19, 161-169.

Crangle, R.D., Jr. (2013), Diatomite. U.S. Geological Survey, Minerals Yearbook, 22.1-22.5.

Creager, J.S., D.W. Scholl et al. (1973), Initial Reports of the Deep Sea Drilling Project. Washington: U.S. Government Printing Office, 19, 1-913.

Farrell, J.W., I. Raffi, T.R. Janecek, D.W. Murray, M. Levitan, K.A. Dadey, K.-C. Emeis, M. Lyle, J.-A. Flores, and S. Hovan (1995), Late Neogene sedimentation patterns in the eastern equatorial Pacific Ocean, Pisias, N.G., L.A. Mayer, T.R. Janecek, A. Palmer-Julason, and T.H. van Andel (eds.), Proceedings of the Ocean Drilling Program, Scientific Results. Texas: College Station, 138, 717-756.

Flower, B.P. and J.P. Kennett (1993), Middle Miocene oceanclimate transition: High-resolution oxygen and carbon isotopic records from Deep Sea Drilling Project Site 588A, southwest Pacific. Paleoceanography, 8(6), 811843.

Fukusawa, H. and I. Koizumi (1994), The comparison between drilling samples in the Japan Sea by ODP and onshore Neogene along the Japan and Okhotsk seas. Monthly Chikyu (Earth), 16, 154-163 (in Japanese).

Garrison, R.E. (1975), Neogene diatomaceous sedimentation in East Asia; a review with recommendations for further study. United Nations ESCAP. CCOP Tech. Bull., 9, 5769.

Garrison, R.E. (1992), Neogene lithofacies and depositional sequences associated with upwelling regions along the eastern margin of the Pacific, Tsuchi, R. and J.C. Ingle, Jr. (eds.), Pacific Neogene-Environment, Evolution, and Events. University of Tokyo Press, 43-69.

Garrison, R.E., L.E. Mack, Y.G. Lee and H.Y. Chun (1979), Petrology, sedimentology and diagenesis of Miocene diatomaceous and opal-CT mudstone in the Pohang area, Korea. Journal of the Geological Societys of Korea, 15, $230-252$.

Gladenkov, Y.B. (1984), Neogene stratigraphy of northeast Asia (Kamchatka and Sakhalin), Ikebe, N. and R. Tsuchi (eds.), Pacific Neogene Datum Planes-Contributions to Biostratigraphy and Chronology. Tokyo: University of Tokyo Press, 235-243.

Gladenkov, A.Yu. (2013a), Neogene diatoms from the deep Hole Central-1, the Bering Sea Chukchi shelf. Micropaleontology, 59, 59-67.

Gladenkov, A.Yu. (2013b), First finds of Eocene diatoms in the marine Paleogene reference section in the II'pinskii Peninsula, northeastern Kamchatika. Stratigraphy and
Geological Correlation, 2013, 21(1), 96-106.

Haq, B.U., J. Hardenbol and P.R.Vail (1987), Chronology of fluctuating sea levels since the Triassic. Science, 235, $1156-1166$.

Haug, G.H., M.A. Maslin, M. Sarnthein, R. Stax and R. Tiedemann (1995), Evolution of northwest Pacific sedimentation patterns since $6 \mathrm{Ma}$ : Site 882 , Rea, D.K., I.A. Basov, D.W. Scholl and J.F. Allan (eds.), Proceedings of the Ocean Drilling Program, Scientific Results. Texas: College Station, 145, 293-314.

Hein, J.R., D.W. Scholl, J.A. Barron, M.G. Jones, and J. Miller (1978), Diagenesis of late Cenozoic diatomaceous deposits and formation of the bottom simulating reflector in the southern Bering Sea. Sedimentology, 25, 155-181.

Ingle, J.C., Jr. (1973), Summary comments on Neogene biostratigraphy, physical stratigraphy, and paleoceanography in the marginal northeastern Pacific Ocean, Kulm, L.D., R. von Huene (eds.), Initial Reports of Deep Sea Drilling Project. Washington: U.S. Govt. Printing Office, 18, 949-960.

Ingle, J.C., Jr. (1975), Summary of late Paleogene-Neogene insular stratigraphy, paleobathymetry, and correlations, Philippine Sea and Sea of Japan region, Karig, D.E., J.C. Ingle, Jr. (eds.), Initial Reports of Deep Sea Drilling Project. Washington: U.S. Govt. Printing Office, 31, 837 855.

Ingle, J.C., Jr. (1981), Origin of Neogene diatomites around the North Pacific rim, Garrison, R.E. and R.G. Dpouglas (eds.), The Monterey Formation and Related Siliceous Rocks of California. Los Angeles: Pacific Section, Society of Paleontologists and Mineralogists, 159-179.

Ingle, J.C., Jr. (1992), Subsidence of the Japan Sea: Stratigraphic evidence from ODP sites and onshore sections, Tamaki, K., K. Suyehiro, J. Allan, M. McWilliams, et al. (eds.), Proceedings of the Ocean Drilling Program, Scientific Results. Texas: College Station, 127/128, 2, 1197-1218.

Isaacs, C.M. (1983), Compositional variation and sequence in the Miocene Monterey Formation Santa Barbara coastal area, California, Larue, D.K. and D.K. Steel (eds.), Cenozoic Marine Sedimentation, Pacific Margin, U.S.A. Soc. Econ. Paleontologists and Mineralogists, Pacific Sec., 117-132.

Janecek, T.R. (2000), Data Report: Late Neogene biogenic opal data for ODP Leg 167 California margin sites, Lyle, M., I. Koizumi, C. Richter and T.C. Moore, Jr. (eds.), Proceedings of the Ocean Drilling Program, Scientific Results. Texas: Texas A\&M University, College Station, $167,13-14$.

Kanaya, T. and I. Koizumi (1966), Interpretation of diatom thanatocoenoses from the north Pacific applied to a study of core V20-130 (Studies of a deep-sea core V20-130, Part IV). Sci. Rep. Tohoku Univ. 2nd Ser. (Geol.), 37, 89- 
130.

Kano, K., K. Uto and T. Ohguchi (2007), Stratigraphic review of Eocene to Oligocene successions along the eastern Japan Sea: Implication for early opening of the Japan Sea. Journal of Asian Earth Sciences, 30, 20-32.

Keller, G. and J.A. Barron (1983), Paleoceanographic implications of Miocene deep-sea hiatuses. Geol. Soc. Am. Bull., 94, 590-613.

Kennett, J.P. (1986), Miocene to early Pliocene oxygen and carbon isotope stratigraphy in the southwest Pacific, Deep Sea Drilling Project Leg 90, Kennett, J.P. and C.C. von der Borch (eds.), Initial Reports of Deep Sea Drilling Project. Washington: U.S. Govt. Printing Office, 90, 1383-1411.

Koizumi, I. (1973), The late Cenozoic diatoms of Sites 183-197, Leg 19 Deep Sea Drilling Project, Creager, J.S., Scholl, D.W., et al. (eds.), Initial Reports of Deep Sea Drilling Project. Washington: U.S. Govt. Printing Office, 19, 805855.

Koizumi, I. (1978), Neogene diatoms from the Sea of Japan. Marine Geology, 26, 231-248.

Koizumi, I. (1983), Sedimentary environments of Neogene diatomaceous sediments, west coast of Japan, Iijima, A., J.R. Hein and R. Siever (eds.), Siliceous Deposits in the Pacific Region. Amsterdam: Elsevier Scientific Publishing Co., Developments in Sedimentology, 36, 347-360.

Koizumi, I. (1988), Early Miocene proto-Japan Sea. The Journal of Paleontological Society of Korea, 4, 6-20.

Koizumi, I. (1990), Successional changes of middle Miocene diatom assemblages in the northwestern Pacific. Palaeogeography, Palaeoclimatology, Palaeoecology, 77, 181-193.

Koizumi, I. (1992), Diatom biostratigraphy of the Japan Sea: Leg 127, Pisciotto, K.A., J.C. Ingle, Jr., M.T. von Breymann, J.A. Barron, et al. (eds.), Proceedings of the Ocean Drilling Program, Scientific Results. Texas: Texas A\&M University, College Station, 127/128, 1, 249-289.

Koizumi, I. (2008), Diatom-derived SSTs ( $T d^{\prime}$ ratio) indicate warm seas off Japan during the middle Holocene (8.23.3 kyr BP). Marine Micropaleontology, 69, 263-281.

Koizumi, I. (2010), Revised diatom biostratigraphy of DSDP Leg 19 drill cores and dredged samples from the subarctic Pacific and Bering Sea. JAMSTEC Reports of Research and Development, 10, 1-21.

Koizumi, I. and T. Sakamoto (2003), Paleoceanography off Sanriku, northeast Japan, based on diatom flora, Suyehiro, K., I.S. Sacks, G.D. Acton and M. Oda (eds.), Proceedings of the Ocean Drilling Program, Scientific Results. Texas: Texas A\&M University, College Station, 186, 1-21 (online).
Koizumi, I. and Y. Tanimura (1985), Neogene diatom biostratgraphy of the middle latitude western north Pacific, Deep Sea Drilling Project Leg 86, Heath, G.R., L.H. Burckle, et al. (eds.), Initial Reports of the Deep Sea Drilling Project. Washington: U.S. Govt. Printing Office, 86, 269-300.

Koizumi, I. and H. Yamamoto (2013), Paleoceanography since the warm Pliocene epoch in the mid-latitudes of the northwestern Pacific Ocean, Bour, F.C. (ed.), Diatoms: Diversity and Distribution, Role in Biotechnology and Environmental Impact. New York: Nova Biomedical, 87106.

Koizumi, I. and H. Yamamoto (2017), Diatomite-diatomaceous sediments in the northwest Pacific area, Veress, B. and J. Szigethy (eds.), Horizon in Earth Science Research, 15, 25-51.

Koizumi, I., M. Sato, and Y. Matoba (2009), Age and significance of Miocene diatoms and diatomaceous sediments from northeast Japan. Palaeogeography, Palaeoclimatology, Palaeoecology, 272, 85-98.

Lyle, M., K.A. Dadey, and J.W. Farrell (1995), The late Miocene (11-8 Ma) Eastern Pacific carbonate crash: evidence for reorganization of deep-water circulation by ther closure of the Panama Gateway, Pisias, N.G., L.A. Mayer, T.R. Janecek, A. Palmer-Julason and T.H. van Andel (eds.), Proceedings of the Ocean Drilling Program, Scientific Results. Texas: College Station, 138, 821-838.

Lyle, M., I. Koizumi, C. Richter, et al. (1997), Proceedings of the Ocean Drilling Program, Initial Reports. 167. Texas: College Station, TX, Ocean Drilling Program.

Lyle, M., I. Koizumi, M.L. Delancey and J.A. Barron (2000), Sedimentary record of the California Current system, middle Miocene to Holocene: A synthesis of Leg 167 results, Lyle, M., I. Koizumi, C. Richter and T.C. Moore, Jr. (eds.), Proceedings of the Ocean Drilling Program, Scientific Results. Texas: Texas A\&M University, College Station, 167, 341-376.

Mammerickx, J. (1985), A deep-sea thermohaline flow path in the northwest Pacific. Marine Geology, 65, 1-19.

Maruyama, T. (2000), Middle Miocene to Pleistocene diatom stratigraphy of Leg 167, Lyle, M., I. Koizumi, C. Richter and T.C. Moore, Jr. (eds.), Proceedings of the Ocean Drilling Program, Scientific Results. Texas: Texas A\&M University, College Station, 63-110.

Miller, K.G., J.D. Wright and R.G. Fairbanks (1991), Unlocking the ice house: Oligocene-Miocene oxygen isotopes, eustacy and margin erosion. J. Geophys. Res., 96, 68296848.

Okada, H. and K. Kobayashi (1974), Paleoenvironments of seafloor based on sediments. Kagaku (Sciences), 44, 212221 (in Japanese). 
Prueher, M.R. and D.K. Rea (1998), Rapid onset of glacial conditions in the subarctic North Pacific region at 2.67 Ma: clues to causality. Geology, 26, 1027-1030.

Pagani, M., M.A. Arthur and K.H. Freeman (1999), Miocene evolution of atmospheric carbon dioxide. Paleoceanography, 14(3), 273-292.

Rea, D.K., I.A. Bsov, D.W. Scholl and J.F. Allan (1995a), Proceedings of the Ocean Drilling Program, Scientific Results. 145. Texas: College Station, TX, Ocean Drilling Program, 1-596.

Rea, D.K., I.A. Basov, L.A. Krissek and the Leg 145 Scientific Party (1995b), Scientific results of drilling the North Pacific transect, Rea, D.K., I.A. Bsov, D.W. Scholl and J.F. Allan, Proceedings of the Ocean Drilling Program, Scientific Results. 145. Texas: College Station, TX, Ocean Drilling Program, 577-596.

Sancetta, C. and S.M. Silvestri (1986), Pliocene-Pleistocene evolution of the north Pacific ocean-atmosphere system, interpreted from fossil diatoms. Paleoceanography, 1, 163-0180.

Scholl, D.W., J.R. Hein, M. Marlow and E.C. Bufungton (1977), Meiji sediment tongue: North Pacific evidence for limited movement between the Pacific and North American plates. Geol. Soc. Am. Bull., 88, 1567-1576.

Sheshukova-Poretzkaya, V.S. (1968), Neogene marine Bacillariophyta of the Far East, Jousé, A.P. (ed.), Fossil Diatoms of the Soviet Union.Izd. Akad. Nauk S.S.S.R. Moscow, 1-26 (in Russian).

Shipboard Scientific Party (1980), Site 435: Japan Trench upper slope, Leg 56, Scientific Party (ed.), Initial Reports of the Deep Sea Drilling Project. Washington: U.S. Govt. Printing Office, 56 and 57, 193-223.

Shipboard Scientific Party (1985a), Site 579, Heath, G.R., L.H. Burckle, et al. (eds.), Initial Reports of the Deep Sea Drilling Project. Washington: U.S. Govt. Printing Office, 86, 175-207.

Shipboard Scientific Party (1985b), Site 580, Heath, G.R., L.H. Burckle, et al. (eds.), Initial Reports of the Deep Sea Drilling Project. Washington: U.S. Govt. Printing Office, 86, 209-221.

Shipboard Scientific Party (1990a), Site 794, Tamaki, K., K. Pisciotto, J. Allan, et al. (eds.), Proceedings of the Ocean Drilling Program, Initial Reports. Texas: Texas A\&M University, College Station, 127, 71-167.

Shipboard Scientific Party (1990b), Site 795, Tamaki, K., K. Pisciotto, J. Allan, et al. (eds.), Proceedings of the Ocean Drilling Program, Initial Reports. Texas: Texas A\&M University, College Station, 127, 169-245.

Shipboard Scientific Party (1990c), Site 797, Tamaki, K., K. Pisciotto, J. Allan, et al. (eds.), Proceedings of the Ocean Drilling Program, Initial Reports. Texas: Texas A\&M
University, College Station, 127, 323-421.

Shipboard Scientific Party (1993a), Site 881, Rea, D.K., L.A. Basov, T.R. Janecek, A. Palmer-Julson, et al. (eds.), Proceedings of the Ocean Drilling Program, Initial Reports. Texas: Texas A\&M University, College Station, 145, 37-83.

Shipboard Scientific Party (1993b), Site 883, Rea, D.K., L.A. Basov, T.R. Janecek, A. Palmer-Julson, et al. (eds.), Proceedings of the Ocean Drilling Program, Initial Reports. Texas: Texas A\&M University, College Station, 145, 121-208.

Shipboard Scientific Party (1993c), Site 884, Rea, D.K., L.A. Basov, T.R. Janecek, A. Palmer-Julson, et al. (eds.), Proceedings of the Ocean Drilling Program, Initial Reports. Texas: Texas A\&M University, College Station, 145,209-302.

Shipboard Scientific Party (1993d), Sites 885/8861, Rea, D.K., L.A. Basov, T.R. Janecek, A. Palmer-Julson, et al. (eds.), Proceedings of the Ocean Drilling Program, Initial Reports. Texas: Texas A\&M University, College Station, 145, 303-334.

Shipboard Scientific Party (1993e), Site 887, Rea, D.K., L.A. Basov, T.R. Janecek, A. Palmer-Julson, et al. (eds.), Proceedings of the Ocean Drilling Program, Initial Reports. Texas: Texas A\&M University, College Station, 145, 335-391.

Shipboard Scientific Party (1997a), Site1021, Lyle, M., I. Koizumi, C. Richter, et al. (eds.), Proceedings of the Ocean Drilling Program, Initial Reports, 167: Collge Station, TX (0cean Drilling Program), 461-495.

Shipboard Scientific Party (1997b), Site1016, Lyle, M., I. Koizumi, C. Richter, et al. (eds.), Proceedings of the Ocean Drilling Program, Initial Reports, 167: Collge Station, TX (0cean Drilling Program), 239-284.

Shipboard Scientific Party (1997c), Site1011, Lyle, M., I. Koizumi, C. Richter, et al. (eds.), Proceedings of the Ocean Drilling Program, Initial Reports, 167: Collge Station, TX (0cean Drilling Program), 85-128.

Shipboard Scientific Party (1997d), Site1010, Lyle, M., I. Koizumi, C. Richter, et al. (eds.), Proceedings of the Ocean Drilling Program, Initial Reports, 167: Collge Station, TX (0cean Drilling Program), 49-84.

Shipboard Scientific Party (2000), Site 1150, Sacks, I.S., K. Suyehiro, G.D. Acton, et al. (eds.), Proceedings of the Ocean Drilling Program Program, Initial Reports, 186: Collge Station, TX (0cean Drilling Program), 193-223.

Stabeno, P.J., J.D. Schumacher, and K. Ohtani (1999), The physical oceanography of the Bering Sea, Loughlin, T.R. and K. Ohtani (eds.), Dynamics of the Bering Sea: A Summary of Physical, Chemical, and Biological Characteristics, and a Synopsis of Research on the Bering 
Sea. Fairbanks: University of Alaska Sea Grant, 1-28.

Takahashi, K. and the Expedition 323 Scientists (2011), Proceedings of the Integrated Ocean Drilling Program. Tokyo: Integrated Ocean Drilling Program Management International, Inc; 323, <https://iodp.tamu.edu/ scienceops/expeditions/bering_sea.html $>$.

Tamaki, K., K. Suyehiro, J. Allan, J.C. Ingle, Jr., and K. Pisciotto (1992), Tectonic synthesis and implications of Japan Sea ODP drilling, Tamaki, K., K. Suyehiro, J. Allan, M. McWilliams, et al. (eds.), Proceedings of the Ocean Drilling Program, Scientific Results. Texas: College Station, 127/128, 2, 1333-1348.

The Shipboard Scientific Party (1973), Site 173, Kulm, L.D., R. von Huene, et al. (eds.), Initial Reports of Deep Sea Drilling Project. Washington: U.S. Govt. Printing Office, 18, 31-95.

The Shipboard Scientific Party (1973a), Site 185, Creager, J.S., D.W. Scholl, et al. (eds.), Initial Reports of Deep Sea Drilling Project. Washington: U.S. Govt. Printing Office, 19, 169-216.

The Shipboard Scientific Party (1973b), Site 188, Creager, J.S., D.W. Scholl, et al. (eds.), Initial Reports of Deep Sea Drilling Project. Washington: U.S. Govt. Printing Office, 19, 291-323.

The Shipboard Scientific Party (1973c), Site 190, Creager, J.S., D.W. Scholl, et al. (eds.), Initial Reports of Deep Sea Drilling Project. Washington: U.S. Govt. Printing Office, 19, 371-411.

The Shipboard Scientific Party (1973d), Site 192, Creager, J.S., D.W. Scholl, et al. (eds.), Initial Reports of Deep Sea Drilling Project. Washington: U.S. Govt. Printing Office, 19, 463-553.

White, L.D., R.E. Garrison, and J.A. Barron (1992), Miocene intensification of upwelling along the California margin as recorded in siliceous facies of the Monterey Fiormation and offshore DSDP sites, Summerhayes, C.P., W.L. Prell and K.C. Emeis (eds.), Upwelling System: Evolution Since the Early Miocene. Geological Society Special Publication 64, 429-442.

Woodruff, F. and S. Savin (1991), Mid-Miocene isotope stratigraphy in the deep sea: High-resolution correlations, paleoclimatic cycles, and sediment preservation. Paleoceanography, 6, 755-806.

Woodruff, F., S.M. Savin, and R.G. Douglas (1981), Miocene stable isotope record: a detailed deep Pacific Ocean study and its paleoclimatic implications. Science, 212, 665668.

Zachos, JC., L. Pagani, L. Sloan, E. Thomas, and K. Billups (2001), Trends, rhythms and aberrations in global climate 65 Ma to present. Science, 292, 686-693. 